\title{
Ligand competition assays indicate allosterism and insufficiency of the ternary complex model
}

This article was published in the following Dove Press journal:

Journal of Receptor, Ligand and Channel Research

10 July 2010

Number of times this article has been viewed

\section{Eyad Qunaibi ${ }^{\prime}$ \\ Roger Barber ${ }^{2}$}

'Formerly (during the time of the study): School of Pharmacy, University of Houston, Houston, TX. At present: School of Pharmacy, Applied Sciences University, Amman, Jordan; ${ }^{2}$ Formerly (during the time of the study): Department of Integrative Biology and Pharmacology, University of Texas/Houston, Houston, TX, USA
Correspondence: Eyad Qunaibi Department of Clinical Pharmacy and Therapeutics, Faculty of Pharmacy, Applied Sciences University, PO Box 23002, Amman IIIII5, Jordan

Tel 00962-79529-6706

Fax 00962-64775 I42

Email eyadqunaibi@yahoo.com
Background: Many researchers have tried to correlate characteristics of ligand binding at G-protein-coupled receptor (GPCR) with ligand efficacy. The ternary complex model (TCM) is the traditional model for explaining the equilibrium of agonist-GPCR-G-protein interaction, and the effect of this interaction on agonist efficacy. However, no consistent correlation has been proven for various binding-efficacy data, so several extensions of the model have been proposed. These extensions are of descriptive value but their validity cannot be verified by binding-efficacy correlations. Therefore, we developed a novel approach to validate the TCM and its extensions.

Methods: We simulated the predictions of the TCM for relationships within binding parameters. According to the TCM, an increase in the difference between high and low agonist affinities for a receptor (ie, greater $\mathrm{K}_{\mathrm{L}} / \mathrm{K}_{\mathrm{H}}$ ) should be accompanied by stability or an increase in the fraction of receptors bound to the agonist with high affinity $\left(\boldsymbol{R}_{\mathrm{H}}\right)$. To validate these predictions we performed ligand competition experiments for a set of $\beta_{2}$-adrenergic receptor (AR) agonists and analyzed the resulting binding data as well as data taken from relevant literature.

Results: No smooth relationship exists between $\boldsymbol{R}_{\mathrm{H}}$ and $\mathrm{K}_{\mathrm{L}} / \mathrm{K}_{\mathrm{H}}$ in our or others' data, indicating the insufficiency of the TCM and its extensions. We introduce the allosteric modulators model as an alternative.

Conclusions: To our knowledge, this is the first paper in which insufficiency of the TCM and its extensions based on binding data are shown, and the first in which the presence of allosteric modulators of ligand affinity is proven to be a necessity for explaining binding data at GPCRs.

Keywords: G-protein-coupled receptor, ternary complex model, allosteric modulators model, fraction of high affinity receptors, ratio of high and low receptor affinities for agonist, bindingfunctional correlations

Traditionally, ligand-binding assays have been used as a first line filter for the process of selecting new chemical entities (NCEs) that have high affinity for a receptor of interest, and for predicting their efficacy at that receptor. A wide variety of responses beyond the agonist-receptor level have been used to express agonist efficacy at guanyl nucleotide-binding protein (G-protein) coupled receptors. This involves, for example, agonist-induced binding of GTP to G-protein, adenylate cyclase activation, and inositol phosphate production.

Introduction of the ternary complex model (TCM) gave the theoretical basis for trying to correlate ligand efficacy with relative affinities of the ligand for receptors uncoupled versus coupled to G-protein $\left(\mathrm{K}_{\mathrm{L}} / \mathrm{K}_{\mathrm{H}}\right)$ (where $\mathrm{K}_{\mathrm{L}}$ is the dissociation constant for binding of agonist to low affinity receptor sites and $\mathrm{K}_{\mathrm{H}}$ is the dissociation constant 
for binding of agonist to high affinity receptor sites) or, less commonly, the fraction of receptors with high affinity for the ligand $\left(\boldsymbol{R}_{\mathrm{H}}\right.$, or the fraction of receptors binding the agonist with high affinity at saturating agonist concentrations) in numerous studies. ${ }^{1-28}$ However, these correlations have varied from highly significant to completely absent. Several extensions and assumptions have been proposed that accommodate, to some extent, this variability in correlation. . $17,21,29-33^{-3}$

One has to bear in mind, however, that the very core concept in the TCM of a ligand-receptor-G protein hierarchy does not put limits on the binding-efficacy correlation; ie, it does not predict a sole or even a restricted range of correlations, disproving that which invalidates the model itself. This precludes using binding-functional correlations to validate the TCM. For example, one can hypothesize that the receptor conformation induced by an agonist to couple to G-protein (the active conformation) is the same for all agonists. By this hypothesis, agonists differ in the fraction of receptors which they put in the active conformation. One could also hypothesize that higher stability of the ternary complex is equal to forming more of the active conformation which, therefore, causes more activation of G-protein and of the downstream effector system. It follows that the agonist which has a higher $\log \mathrm{K}_{\mathrm{L}} / \mathrm{K}_{\mathrm{H}}$ should have a higher efficacy in activating an effector system. Notice that these assumptions are not consequences of the TCM but limitations put on the model to enable deriving relationships between binding parameters and efficacy.

If, however, an agonist with a higher $\log \mathrm{K}_{\mathrm{L}} / \mathrm{K}_{\mathrm{H}}$ is found experimentally to be less efficacious, then explanations can be made that challenge the assumptions added to the TCM but not the TCM per se. For example, it can be said that different conformations are induced by the different agonists. 2,29,30,33 In this context, an agonist with a higher $\log \mathrm{K}_{\mathrm{L}} / \mathrm{K}_{\mathrm{H}}$ can induce a conformation that couples highly to G-protein but activates it less efficiently than the conformation induced by an agonist with a lower $\log \mathrm{K}_{\mathrm{L}} / \mathrm{K}_{\mathrm{H}}$. Alternatively, it can be said that all agonists induce the same type of conformation that couples to G-protein, but that the receptor then needs to switch to another conformation that activates G-protein. In this context, it can be postulated that an agonist with a higher $\log \mathrm{K}_{\mathrm{L}} / \mathrm{K}_{\mathrm{H}}$ will be less efficacious in activating adenylate cyclase $(\mathrm{A} / \mathrm{C})$, not because it cannot induce coupling of receptor to G-protein, but because the coupling it induces is so tight that the receptor cannot switch to the form which activates G-protein. $^{2}$

The above-clarified fluidity of the binding-functional correlations precludes using them to validate the sufficiency of the TCM and its extensions and modifications. The TCM extensions are valuable in incorporating inevitable observations (like constitutive activity) and accommodating broadly variable data. To validate a model, however, it is not enough to show that it 'accommodates' data. Rather, its 'predictions' need to be proven. The interplay of the many equilibrium constants in the TCM extensions combined with the modifications (like different conformations and promiscuity) gives countless possibilities of efficacy outcomes rather than a single testable prediction.

In this paper, we introduce a novel approach to test the sufficiency of the TCM and its extensions. We show that, unlike with binding-functional correlations, the TCM predicts definite relationships within the binding parameters. We simulated these relationships and ran accurate binding experiments for a series of $\beta_{2}$-adrenergic receptor $\left(\beta_{2}\right.$-AR) agonists, analyzing binding data for various GPCRs in the literature. We then compared our and others' data with the simulations and formed conclusions on the sufficiency of the TCM.

\section{Materials and methods}

\section{Simulation of the relationship within binding parameters}

We here simulate the relationship between $\boldsymbol{R}_{\mathrm{H}}$ and $\mathrm{K}_{\mathrm{L}} / \mathrm{K}_{\mathrm{H}}$ according to the TCM. Following are the equilibrium and equations that describe the ternary complex model:

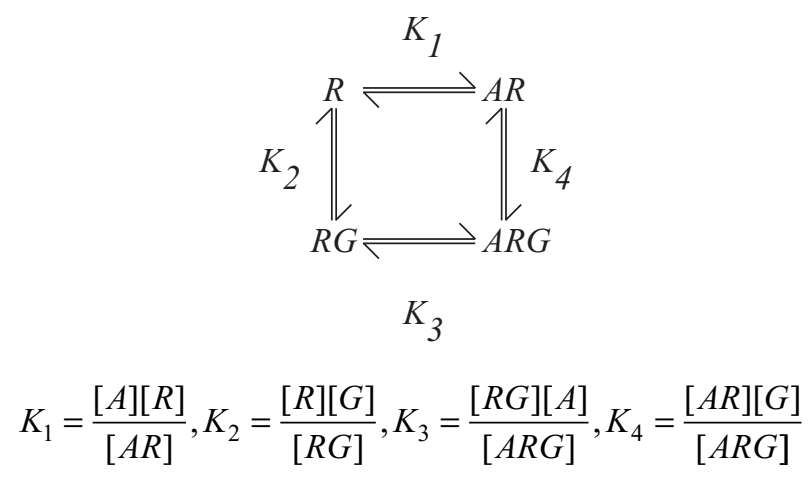

Where $\mathrm{R}$ is the receptor, $\mathrm{A}$ is the agonist, and $\mathrm{G}$ is the G-protein heterotrimer. We will refer to the association of the receptor with the agonist as binding and the association of the receptor with G-protein as coupling in the present study.

According to the TCM, the receptors that are coupled to G-protein have a high affinity for agonist $\left(\mathrm{K}_{\mathrm{H}}\right)$ while those that are not coupled have a low affinity $\left(\mathrm{K}_{\mathrm{L}}\right)$. Experimentally, incremental concentrations of this agonist can be incubated with a receptor system that is prebound to an antagonist and the curve of antagonist displacement by the agonist analyzed. 
From this analysis we can determine $\mathrm{K}_{\mathrm{L}}, \mathrm{K}_{\mathrm{H}}$, and $\boldsymbol{R}_{\mathrm{H}}$, the apparent fraction of receptors that should bind the agonist with high affinity at saturating agonist concentrations.

To define the predictions of the TCM for the relationship between $\mathrm{K}_{\mathrm{L}} / \mathrm{K}_{\mathrm{H}}$ and $\boldsymbol{R}_{\mathrm{H}}$, we elaborate first on the affinity constants in the equilibrium above $\left(\mathrm{K}_{1}-\mathrm{K}_{4}\right)$ and explain how they relate to the affinity constants $\left(\mathrm{K}_{\mathrm{L}}\right.$ and $\left.\mathrm{K}_{\mathrm{H}}\right)$ obtained from a 2-site analysis of ligand competition curves. In the TCM equilibrium, a low $\mathrm{K}_{2}$ value indicates that coupling of receptors to G-protein in the absence of agonist is highly likely, and is therefore agonist-independent (constitutive). A high $\mathrm{K}_{2}$ value, in contrast, indicates that coupling of receptors to G-protein in the absence of agonist is highly unlikely, and is therefore agonist-dependent. $\mathrm{K}_{\mathrm{L}}$ of 2-site analysis is equal to $\mathrm{K}_{1}$ according to TCM. On the other hand, correlating $\mathrm{K}_{\mathrm{H}}$ of 2-site analysis with the equilibrium above is more complex and depends on whether coupling of receptors to G-protein is agonist-dependent or agonist-independent. When coupling is completely agonistindependent, $\mathrm{K}_{\mathrm{H}}=\mathrm{K}_{3}$. When coupling is agonist-dependent, $\mathrm{K}_{\mathrm{H}}$ is approximated by $\mathrm{K}_{2} \cdot \mathrm{K}_{3}$ because formation of the ternary complex in this case depends on the energetically unfavorable coupling of receptor to G-protein (represented by $\mathrm{K}_{2}$ ) and the energetically favorable binding of agonist to the coupled receptor (represented by $\mathrm{K}_{3}$ ). For a system with a given $\mathrm{K}_{2}$, a greater $\mathrm{K}_{\mathrm{L}} / \mathrm{K}_{\mathrm{H}}$ indicates that the preference of binding to coupled receptors is higher than when $\mathrm{K}_{\mathrm{L}} / \mathrm{K}_{\mathrm{H}}$ is smaller.

For any given membrane preparation, the relationship between $\mathrm{K}_{\mathrm{L}} / \mathrm{K}_{\mathrm{H}}$ and $\boldsymbol{R}_{\mathrm{H}}$ depends on whether the coupling of receptor to G-protein is agonist-dependent or agonistindependent. We present both extremes here to define the upper and lower limits of $\boldsymbol{R}_{\mathrm{H}}$ that the TCM allows, in theory, for an agonist with a given $\mathrm{K}_{\mathrm{L}} / \mathrm{K}_{\mathrm{H}}$. When coupling is agonistindependent, the magnitude of $\boldsymbol{R}_{\mathrm{H}}$ is predetermined by the extent of constitutive coupling (precoupling). Therefore, a higher $\mathrm{K}_{\mathrm{L}} / \mathrm{K}_{\mathrm{H}}$ should be reflected in a higher preference of the agonist for $\mathrm{RG}$ than for $\mathrm{R}$, but not in an increase in $\boldsymbol{R}_{\mathrm{H}}$. We should keep in mind here that absolute agonist independence is unlikely because it does not leave space for agonism, but it is assumed here in order to draw the upper limit.

When, on the other hand, the coupling of receptor to G-protein is agonist-dependent, a higher $\mathrm{K}_{\mathrm{L}} / \mathrm{K}_{\mathrm{H}}$ should be reflected not only in more preference for $\mathrm{RG}$, but also in an increase in receptor coupling to G-protein (higher $\boldsymbol{R}_{\mathrm{H}}$ ). In conclusion, the TCM necessitates that $\boldsymbol{R}_{\mathrm{H}}$ values for different agonists at the same receptor system should be either the same or higher for the agonist that has a higher $\mathrm{K}_{\mathrm{L}} / \mathrm{K}_{\mathrm{H}}$ in a predictable manner depending on the extent of constitutive coupling of receptor to G-protein.
In the Results section, we show experimental $\boldsymbol{R}_{\mathrm{H}}-\log$ $\mathrm{K}_{\mathrm{L}} / \mathrm{K}_{\mathrm{H}}$ relationships along with an upper line and a lower curve representing, respectively, the extremes of agonistdependent and agonist-independent coupling. For the TCM to be valid, experimental $\boldsymbol{R}_{\mathrm{H}}$ should form a smooth curve between these two extremes at a position that depends on the level of agonist-independent precoupling (the value of $\mathrm{K}_{2}$ ).

To draw the upper and lower limits of $\boldsymbol{R}_{\mathrm{H}}$ throughout this project, we followed several steps. First, we assumed a 100\% and $\sim 0 \%$ precoupling for upper and lower limits of $\boldsymbol{R}_{\mathrm{H}}$, respectively. Drawing the lower limit is laborious; $\sim 0 \%$ precoupling was simulated by first assuming a very large value for the equilibrium constant of precoupling (ie, $\mathrm{K}_{2}=1000$ ).

We assumed that the ratio of G-protein to receptor is equal to $110 \%$ of the $\boldsymbol{R}_{\mathrm{H}}$ of the experimental agonist with the highest $\boldsymbol{R}_{\mathrm{H}}$ value. We also assumed an equilibrium constant for binding of agonist to uncoupled receptor $\left(\mathrm{K}_{1}\right.$ in the equilibrium above) of $1 \times 10^{-6} \mathrm{M}$. This value is arbitrary, but selected to be at a fairly typical value for low affinity binding of an agonist. We then constructed a spreadsheet in which we put equations to solve for [ARG] and [AR] based on $\mathrm{K}_{1}, \mathrm{~K}_{2}$, and $\mathrm{K}_{3}$ values, theoretical agonist concentrations, and the assumed concentration of G-protein (derivations of equations are presented in Supplement 1). $\mathrm{K}_{3}$ was varied to obtain a range of $\log \mathrm{K}_{\mathrm{L}} / \mathrm{K}_{\mathrm{H}}$ values. From $[\mathrm{ARG}]$ and $[\mathrm{AR}]$, the spreadsheet was used to calculate fractions of sites available for antagonist at different agonist concentrations. When these fractions were plotted against the logarithm of agonist concentration, a 2-site curve was obtained. From the analysis of this curve (by Graph Pad software), $\boldsymbol{R}_{\mathrm{H}}$ was obtained for each $\log \mathrm{K}_{\mathrm{L}} / \mathrm{K}_{\mathrm{H}} \cdot \boldsymbol{R}_{\mathrm{H}}$ was then plotted against $\log \mathrm{K}_{\mathrm{L}} / \mathrm{K}_{\mathrm{H}}$ and the relationship was taken as the theoretical lower limit of $\boldsymbol{R}_{\mathrm{H}}$.

Drawing the upper limit of $\boldsymbol{R}_{\mathrm{H}}$ is straightforward. It is approximated by the plateau, with incremental $\log$ $\mathrm{K}_{\mathrm{L}} / \mathrm{K}_{\mathrm{H}}$ values, of $\boldsymbol{R}_{\mathrm{H}}$ values simulated for the extreme of no precoupling.

In Figure 1 we simulate the impact the degree of precoupling has, in the context of the TCM, on $\boldsymbol{R}_{\mathrm{H}}$ values for theoretical agonists with different $\log \mathrm{K}_{\mathrm{L}} / \mathrm{K}_{\mathrm{H}}$ values. $\boldsymbol{R}_{\mathrm{H}}$ in this figure is obtained from quantitative derivations based on the TCM (Supplement 1) combined with 2-site fit. Assuming that we know the $\boldsymbol{R}_{\mathrm{H}}$ value (say 0.65) for an agonist (A) with a defined $\log \mathrm{K}_{\mathrm{L}} / \mathrm{K}_{\mathrm{H}}$ (say 3.2) in certain experimental conditions, and want to know what the TCM predicts $\boldsymbol{R}_{\mathrm{H}}$ to be for an agonist (B) that has a lower $\log \mathrm{K}_{\mathrm{L}} / \mathrm{K}_{\mathrm{H}}$ (say 0.7). As can be seen in Figure 1, the TCM does not predict a certain exact value, but a range of values for $\boldsymbol{R}_{\mathrm{H}}$ (in this case ranging from 0.4 to 0.65 ), depending on the extent of precoupling of the 


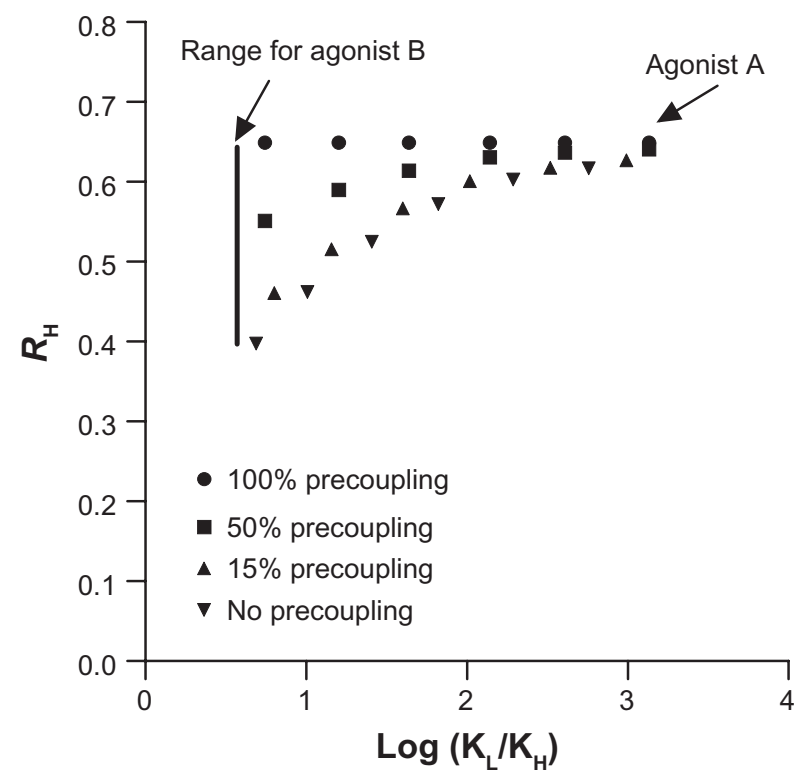

Figure I A simulation for the effect of constitutive coupling (precoupling) of receptor to $\mathrm{G}$-protein on the relationship between $\boldsymbol{R}_{\mathrm{H}}$ and $\log \mathrm{K}_{\mathrm{L}} / \mathrm{K}_{\mathrm{H}} . \mathrm{K}_{\mathrm{L}}$ and $\mathrm{K}_{\mathrm{H}}$, low and high affinity constants of receptor for agonist, respectively; $\boldsymbol{R}_{\mathrm{H}}$, fraction of receptors in the high affinity state at saturating agonist concentrations. $G / R$ ratio was fixed at 0.65 .

receptors. This argument can be extended to any number of agonists, keeping in mind that the degree of receptor precoupling should have the same impact on all agonists regardless of its magnitude. Therefore, $\boldsymbol{R}_{\mathrm{H}}$ versus $\log \mathrm{K}_{\mathrm{L}} / \mathrm{K}_{\mathrm{H}}$ relationship should form a smooth curve which falls between the two limits of $0 \%$ and $100 \%$ precoupling.

From this discussion, we can see that the TCM predicts definite relationships between the binding parameters of an agonist $\left(\boldsymbol{R}_{\mathrm{H}}\right.$ and $\left.\mathrm{K}_{\mathrm{L}} / \mathrm{K}_{\mathrm{H}}\right)$. If these relationships are shown not to be valid, the TCM is then insufficient.

Here we have two important notes. First, it may be argued that obtaining data inconsistent with our simulations invalidates a 'restricted version' of the TCM which included the arbitrary values denoted for $\mathrm{G} / \mathrm{R}$ ratio, $\mathrm{K}_{1}$, and $\mathrm{K}_{2}$ in our simulations, so choosing a different set of equilibrium values would modify the lower limit curve and accommodate the data. In response, no matter how these values are manipulated, upper and lower limits will be obtained within which the $\boldsymbol{R}_{\mathrm{H}}$ versus $\log \mathrm{K}_{\mathrm{L}} / \mathrm{K}_{\mathrm{H}}$ relationship should form a curve if the TCM is sufficient. Second, upper and lower relationship limits are also imposed by all TCM extensions and modifications which limit the interaction to a 'ternary' complex; ie, do not incorporate the concept of other players that modify receptor affinity for ligand. For example, in the modification that assumes ligand-specific conformations, the term for $\mathrm{K}_{\mathrm{L}}$ is:

$\mathrm{K}_{\mathrm{L}}=\mathrm{K}_{\mathrm{a}} \times f_{\mathrm{RaA}}+\mathrm{K}_{\mathrm{b}} \times f_{\mathrm{RbA}} \ldots$ where $\mathrm{K}_{\mathrm{a}}$ is the affinity constant for conformation a, and $f_{\mathrm{RaA}}$ is the fraction of this conformation of all low-affinity conformations at saturating agonist concentrations. It follows that affinity and fraction terms are still related and the microscopic $\mathrm{K}_{\mathrm{L}}$ 's, $\mathrm{K}_{\mathrm{H}}$ 's, and $\boldsymbol{R}_{\mathrm{H}}$ 's for individual conformations are all reflected in the macroscopic $\mathrm{K}_{\mathrm{L}}$ 's, $\mathrm{K}_{\mathrm{H}}$ 's, and $\boldsymbol{R}_{\mathrm{H}}$ 's obtained from 2-site analysis.

In our simulations, we assume that $\boldsymbol{R}_{\mathrm{H}}$ is equal to fRGA (fraction of RGA at saturation agonist concentrations). However, we should mention here that the extent of identity between $\boldsymbol{R}_{\mathrm{H}}$ and fRGA depends on whether coupling of receptor to G-protein is agonist-dependent or agonist-independent. In brief, the divergence between $\boldsymbol{R}_{\mathrm{H}}$ and fRGA increases with increased agonist dependence of receptor coupling to G-protein. This is due to the divergence in these conditions between equation 18 and the equation built in the Graph Pad software to obtain $\boldsymbol{R}_{\mathrm{H}}$ :

$$
\left(\frac{\operatorname{Max}_{\text {high }[A]}}{K_{H}+[A]}+\frac{\operatorname{Max}_{\text {low }}[A]}{K_{L}+[A]}\right)
$$

where $\mathrm{Max}_{\text {high }}$ and $\mathrm{Max}_{\text {low }}$ are, respectively, the concentrations of receptors bound to the agonist with high and low affinities at saturating agonist concentrations.

Figure 2 is a simulation for the divergence between $\boldsymbol{R}_{\mathrm{H}}$ and fRGA in the extreme of agonist-dependent coupling (a very large $\mathrm{K}_{2}$ value of 1000). The G-protein/receptor ratio had to be $<1.0$ to conform to the assumption of the TCM of limited $\mathrm{G}$-protein. We assumed a fixed $\mathrm{K}_{1}$ value and then varied the value of $\mathrm{K}_{4}$. At each $\mathrm{K}_{4}$, we calculated the amount of agonist that should bind to the receptor (to form RA and RGA species) at incremental agonist concentrations and followed the same

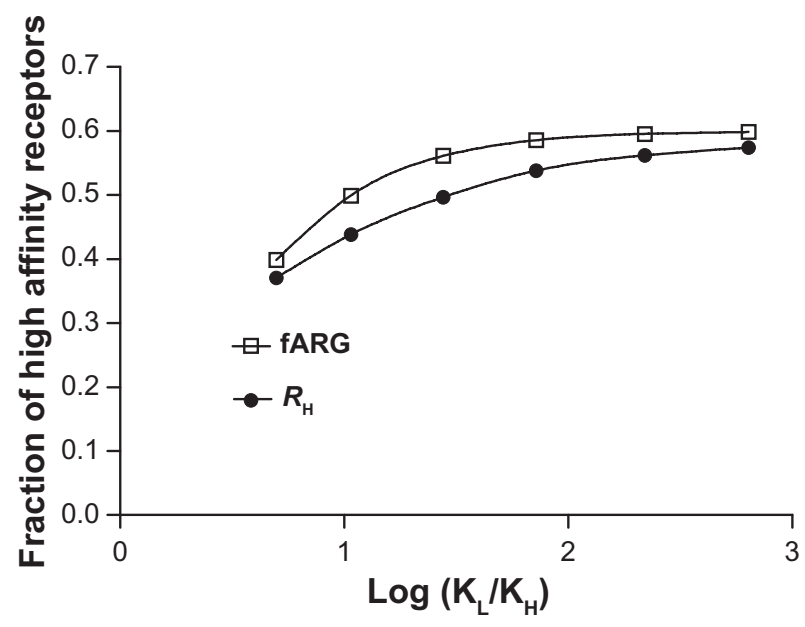

Figure 2 A simulation for the divergence between the fraction of high affinity receptors calculated from equations describing the TCM and that obtained from two-site fit in the extreme of agonist-dependent coupling. The values of $K_{1}, K_{2}, r$, and $g$ were assumed at $10^{-6}, 1000,1$, and 0.6 , respectively. 
steps as above to get $\mathrm{K}_{\mathrm{L}} / \mathrm{K}_{\mathrm{H}}$ and $\boldsymbol{R}_{\mathrm{H}}$ values at that given $\mathrm{K}_{4}$. fRGA was simply taken to be the calculated fraction of RGA species (from the sum of RA and RGA) at saturating agonist concentrations and is given by the equation:

$$
f R G A=\frac{r+g+K_{4}-\sqrt{\left(r+g+K_{4}\right)^{2}-4 r g}}{2}
$$

The same process was repeated for different $\mathrm{K}_{4}$ values. The fraction of receptors with high affinity (calculated fRGA and $\boldsymbol{R}_{\mathrm{H}}$ obtained from Graph Pad analysis) was then plotted against $\log \mathrm{K}_{\mathrm{L}} / \mathrm{K}_{\mathrm{H}}$.

An important note needs to be made here. Although fRGA and $\boldsymbol{R}_{\mathrm{H}}$ in the simulation above are not identical, they are still proportional. Also, the magnitude of divergence shown in the simulation is at maximum because the extreme of no precoupling is assumed. Therefore, $\boldsymbol{R}_{\mathrm{H}}$ should be considered a useful approximation of fRGA.

\section{Analysis of binding data in the literature}

To evaluate whether the relationships between $\boldsymbol{R}_{\mathrm{H}}$ and $\log$ $\mathrm{K}_{\mathrm{L}} / \mathrm{K}_{\mathrm{H}}$ in the literature are consistent with the predictions of the TCM, we analyzed data from studies on a variety of GPCRs including $\alpha_{2}$-adrenergic, ${ }^{20} \beta$-adrenergic, ${ }^{2,4}$ muscarinic, ${ }^{5,11} \mathrm{D}_{2-}$ dopamine, ${ }^{10,12,16,34} \mathrm{~A}_{1}$-adenosine, ${ }^{3}$ and $5-\mathrm{HT}_{1 \mathrm{~A}}$ serotonergic ${ }^{28}$ receptors. We should mention that in none of these studies was the fact that the TCM imposes certain limits for the relationship between $\boldsymbol{R}_{\mathrm{H}}$ and $\log$ $\mathrm{K}_{\mathrm{L}} / \mathrm{K}_{\mathrm{H}}$ discussed, nor was such a relationship suggested for establishment. In only one instance, a note was made that the $\beta$-AR agonists with higher $\log \mathrm{K}_{\mathrm{L}} / \mathrm{K}_{\mathrm{H}}$ ratios had higher $\boldsymbol{R}_{\mathrm{H}} \mathrm{s}\left(P<0.001, R^{2}=0.95\right) .{ }^{4}$ The authors considered this proportionality to signal the validity of the TCM.

\section{Binding experiments}

We performed our own binding experiments because we went one step further, involving introducing a binding parameter that correlates with agonist efficacy (manuscript in preparation). This step needed reliably accurate binding data, as well as choosing the suitable expression of efficacy. In that work, we explain what reservations we have on some efficacy expressions in the literature.

The $\beta_{2}$-AR agonists tested were: epinephrine, isoproterenol, fenoterol, procaterol, albuterol, terbutaline, zinterol, dobutamine, tulobuterol, and ephedrine. The $\beta_{2}$-AR-containing membranes were from S49 mouse lymphoma cells, BEAS.2B human bronchial epithelial cells, or human embryonic kidney cells transfected with hemagglutinin-tagged $\beta_{2}$-ARs $(H \beta A R H$ cells). HBARH membranes were either reconstituted with $\alpha$-stimulatory and $\beta \gamma$-subunits of $\mathrm{G}$-protein $\left(\mathrm{G}_{\mathrm{s} \alpha}\right.$ and $\left.\mathrm{G}_{\beta \gamma}\right)$ or not reconstituted.

The reason why we needed to reconstitute $\mathrm{H} \beta \mathrm{ARH}$ membranes with $\mathrm{H}_{6}-\mathrm{G}_{\mathrm{s} \alpha}$ and $\mathrm{G} \beta \gamma$ in a set of experiments was the low $\boldsymbol{R}_{\mathrm{H}}$ values obtained with the naïve membranes. As expected, reconstitution did increase $\boldsymbol{R}_{\mathrm{H}}$ (from $28.08 \%$ to $58.25 \%$ for epinephrine), thus increasing the sensitivity of these membranes for comparison of different agonists. However, we then harvested another H $\beta$ ARH membrane batch in which epinephrine had an $\boldsymbol{R}_{\mathrm{H}}$ of $\sim 50 \%$, high enough to resolve differences, if any, between $\boldsymbol{R}_{\mathrm{H}}$ s for different $\beta_{2}$-ARs agonists without need for reconstitution. We call this batch of membranes 'naïve' hereafter in the study. The enhanced $\boldsymbol{R}_{\mathrm{H}}$ values we observed with the second batch could be due to better preparation techniques that preserved coupling of receptors to endogenous $\mathrm{G}$-protein.

The low $\beta_{2}$-AR densities in S49 and BEAS.2B membranes put a limit on the number of agonists that could be tested in these membranes.

\section{Materials}

S49 cells were obtained from Dr Henrey Bourne (University of California, San Francisco, CA). BEAS.2B cells, HEK cells transfected with hemagglutinin-tagged $\beta_{2}$-AR, hereafter referred to as $\mathrm{H} \beta \mathrm{ARH}$ cells, and ${ }^{125}$ I-radioactive iodinated cyanopindolol, hereafter referred to as $\left[{ }^{125} \mathrm{I}\right] \mathrm{CYP}$, were kindly provided by Dr Richard Clarke (University of Texas at Houston, Health Science Center, Houston). Ham's F-12 medium, aprotinin, and beta subtype 2 adrenergic receptors, hereafter referred to as $\beta_{2}$-AR agonists, were obtained from Sigma. Fetal bovine and donor horse sera were from Atlanta Biologicals (Norcross, GA). Penicillin and streptomycin were from Mediatech. Tris Base, GTP, and guanosine-51-O-(3-thio)triphosphate (GTP $\gamma \mathrm{S})$ were from Boehringer-Mannheim Biochemicals. Tritiated dihydroalprenolol, hereafter referred to as $\left[{ }^{3} \mathrm{H}\right] \mathrm{DHA}$, and $\left[{ }^{32} \mathrm{P}\right]$ ATP were from Dupont NEN. Multiscreen 96-well plates were from Millipore. $\left[{ }^{3} \mathrm{H}\right] \mathrm{cAMP}$ was from Moravek Biochemicals. The plasmid H6-Gs $\alpha$ pQE60 and the bacteria E. coli $\mathrm{B} 121-\mathrm{DE} 3 / \mathrm{pREP} 4$ were kindly given to the authors by Dr Carmen Dessauer (University of Texas at Houston, Health Science Center, Houston, TX). Ni-NTA agarose resin was purchased from QIAGEN.

\section{Cell culture and membrane preparation}

S49 cells were grown and membranes harvested as described by Krumins et $\mathrm{al}^{35}$ except that buffer B did not contain trypsin inhibitor or leupeptin. 
BEAS.2B cells were grown to confluence in T150 flasks at $37^{\circ} \mathrm{C}$ in sodium bicarbonate-buffered Ham's F-12 medium supplemented with penicillin, streptomycin, and 10\% fetal bovine serum. To split the cells, the medium was removed and the cell monolayer washed with $10 \mathrm{~mL}$ phosphate buffer solution, then $2 \mathrm{~mL}$ of trypsin solution (trypsin $0.25 \%$ and EDTA $0.02 \%$ ) was added to the cell monolayer for 3-5 minutes. Then $10 \mathrm{ml}$ of fresh medium was added and cells were suspended into the medium. For membrane preparation, the cells were passed into cell culture dishes and grown for at least 48 hours. Then the medium was removed by aspiration and the cell monolayer washed twice with $10 \mathrm{~mL}$ cold HE solution (20 mM Hepes, pH8 and 1mM EDTA, pH 7.0). The cells were then scraped into $6 \mathrm{~mL} \mathrm{HE}$ containing the protease inhibitor leupeptin $(10 \mu \mathrm{g} / \mathrm{mL})$. The cells were then homogenized in a type B Dounce homogenizer. Membranes were obtained from the lysate and stored as with S49 lysate with the exception that centrifugation was for 20 minutes.

$\mathrm{H} \beta \mathrm{ARH}$ cells were grown and membranes prepared using the exact same procedures for BEAS.2B cells with two modifications; Hepes-buffered DMEM was used instead of Ham's F-12 medium, and G418 sulfate was included in the growth medium to select for the cells that were stably transformed with hemagglutinin-tagged $\beta_{2}$-ARs.

\section{Preparation of $\mathrm{H}_{6}-\mathrm{G}_{\mathrm{s \alpha}}$ and $\mathrm{H}_{6}-\mathrm{G}_{\beta \gamma}$}

$\mathrm{G}_{\mathrm{s} \alpha}$ tagged with 6 residues of histidine $\left(\mathrm{H}_{6}-\mathrm{G}_{\mathrm{s} \alpha}\right)$ was prepared as described by Lee et al. ${ }^{36} \mathrm{H}_{6}-\mathrm{G}_{\beta \gamma}$ was prepared as described by Iniguez-Lluhi et al. ${ }^{37}$ Protein concentration was determined using the Bradford method. ${ }^{38}$

\section{Reconstitution of $\mathrm{H} \beta A R H$ membranes with $\mathrm{H}_{6}-\mathrm{G}_{\mathrm{s \alpha}}$ and $\mathrm{G}_{\beta \gamma}$}

To reconstitute $\mathrm{H} \beta$ ARH membranes with $\mathrm{H}_{6}-\mathrm{G}_{\mathrm{s} \alpha}$ and $\mathrm{G}_{\beta \gamma}$, a membrane quantity including $\sim 0.66$ pmole $\beta_{2}$-AR, 1 nmole of each of $\mathrm{H}_{6}-\mathrm{G}_{\mathrm{s \alpha}}$ and $\mathrm{G}_{\beta \gamma}$ and $10 \mu \mathrm{l} 0.01 \mathrm{M} \mathrm{MgCl}_{2}$ were vortexed in a vial for 3 minutes. The vial was then put in ice for 15 minutes to be used for one binding experiment.

\section{Ligand competition}

Binding analyses were carried out in $305 \mu$ reactions with a fixed concentration of $\left[{ }^{125} \mathrm{I}\right] \mathrm{CYP}$ or $\left[{ }^{3} \mathrm{H}\right] \mathrm{DHA}$ (75.0 $\mathrm{pM}$ and $1.0 \mathrm{nM}$, respectively), increasing $\beta_{2}$-AR agonist concentrations and an amount of membrane protein containing $8.76 \mathrm{fM}$ of $\beta_{2}-\mathrm{AR}$ (for $\mathrm{S} 49$ and $\mathrm{H} \beta \mathrm{ARH}$ membranes). The reaction mixture contained the following final concentrations of reagents: $18.0 \mathrm{mM}$ Hepes pH 8.0, $2.2 \mathrm{mM} \mathrm{MgCl}, 143.0 \mu \mathrm{M}$ 1-methyl3-isobutylxanthine (MIX), $29.0 \mu \mathrm{M}$ phentolamine, $2.9 \mu \mathrm{M}$ ascorbate, $29.0 \mu \mathrm{M}$ thiourea, and 1.2 mM EDTA pH 7.0. The reaction mixture was incubated for 40 minutes at $30^{\circ} \mathrm{C}$. Nonspecific $\left[{ }^{125} \mathrm{I}\right] \mathrm{CYP}$ binding was determined in the presence of $20 \mu \mathrm{M}$ alprenolol. Not more than $10 \%$ of the amount added of $\left[\mathrm{I}^{125}\right] \mathrm{CYP}$ was bound to filter papers, except in case of BEAS.2B membranes where nonspecific binding was up to $35 \%$. Reactions were terminated by vacuum filtration through $\mathrm{GF} / \mathrm{C}$ filters in 96-well filter plates using Millipore vacuum filtration apparatus and the filters were washed three times with a solution of $10 \mathrm{mM}$ Tris-Cl, $\mathrm{pH} 7.4$ and $5 \mathrm{mM} \mathrm{MgCl}_{2}$. The filters were dried and radioactivity counted using a Beckman Gamma counter for 1 minute. For accuracy enhancement, 13-14 agonist concentrations in quintuplets were used. Specifically bound $\left[\mathrm{I}^{125}\right]$ CYP was plotted against log [agonist] and two-site competition analysis using Graph Pad software version 3.02; Graph Pad, San Diego, CA, yielded values of $\mathrm{K}_{\mathrm{L}}, \mathrm{K}_{\mathrm{H}}$, and $\boldsymbol{R}_{\mathrm{H}}$.

\section{Determination of dissociation constants \\ for radioactive antagonists at $\beta_{2}-A R$ and $\beta_{2}$-AR density}

Similar reaction buffers and conditions were used as in ligand competition assays. Instead of running an agonist-antagonist competition, various concentrations of the radioactive antagonist ( $2-500 \mathrm{pM}$ and $\sim 25-2700 \mathrm{pM}$ for $\left[{ }^{125} \mathrm{I}\right] \mathrm{CYP}$ and $\left[{ }^{3} \mathrm{H}\right]$ DHA, respectively) were incubated with membranes in the presence or absence of $20 \mu \mathrm{M}$ alprenolol. Specifically-bound radioligand concentration was plotted against the logarithm of the free radioligand concentration and a sigmoidal doseresponse analysis using Graph Pad software yielded $\mathrm{IC}_{50}$ values for the radioligands. Cheng-Prussof correction was used to obtain the overall dissociation constant for binding of ligand to receptor $\left(\mathrm{K}_{\mathrm{d}}\right)$ values.

To solve for receptor density we first calculated the concentration of radioactive antagonist bound to receptor at saturation. The receptor density was obtained by dividing the moles of receptor by the concentration of membrane protein.

\section{Analysis of data: statistical significance} Relationships were considered significant at $P<0.05$.

\section{Results}

\section{Analysis of binding data in the literature}

Our analysis of $\boldsymbol{R}_{\mathrm{H}}$ versus $\log \mathrm{K}_{\mathrm{L}} / \mathrm{K}_{\mathrm{H}}$ relationships is represented in Figure 3 and we obtained the following main results. Only in one study ${ }^{11}$ was a relationship within the limits of the TCM obtained. In two other studies ${ }^{3,4}$ significant relationships of higher $\boldsymbol{R}_{\mathrm{H}}$ for agonists with higher $\log \mathrm{K}_{\mathrm{L}} / \mathrm{K}_{\mathrm{H}}$ were obtained, but they fell out of the limits of the TCM. In 
two other studies ${ }^{10,12}$ significant relationships of lower $\boldsymbol{R}_{\mathrm{H}}$ for agonists with higher $\log \mathrm{K}_{\mathrm{L}} / \mathrm{K}_{\mathrm{H}}$ were obtained. In the other seven studies ${ }^{2 \mathrm{a}, 2 \mathrm{~b}, 5,16,20,28,34}$ no significant relationship between $\boldsymbol{R}_{\mathrm{H}}$ and $\log \mathrm{K}_{\mathrm{L}} / \mathrm{K}_{\mathrm{H}}$ was obtained.

\section{Binding experiments}

The relationship between the fraction of $\beta_{2}$-ARs with high affinity for an agonist $\left(\boldsymbol{R}_{\mathrm{H}}\right)$ and the ratio between high and low affinities of $\beta_{2}$-ARs for the agonist $\left(\log \mathrm{K}_{\mathrm{L}} / \mathrm{K}_{\mathrm{H}}\right)$

Figure 4 shows typical ligand competition curves obtained for the agonists tested in H $\beta A R H$ membranes against $\left[{ }^{125} \mathrm{I}\right]$ CYP to determine values of $\boldsymbol{R}_{\mathrm{H}}$ and $\log \mathrm{K}_{\mathrm{L}} / \mathrm{K}_{\mathrm{H}}$ for these agonists.

Figure 5 shows that the experimental $\boldsymbol{R}_{\mathrm{H}} \mathrm{s}$ did not fall within the range predicted by the TCM for a series of $\beta_{2}$-AR agonists that vary in $\log \mathrm{K}_{\mathrm{L}} / \mathrm{K}_{\mathrm{H}}$ in all tested membrane types (S49, BEAS.2B, naïve H $\beta A R H$, and reconstituted $\mathrm{H} \beta A R H$ membranes). Notice, however, that a subset of these agonists (epinephrine, fenoterol, albuterol, terbutaline, and
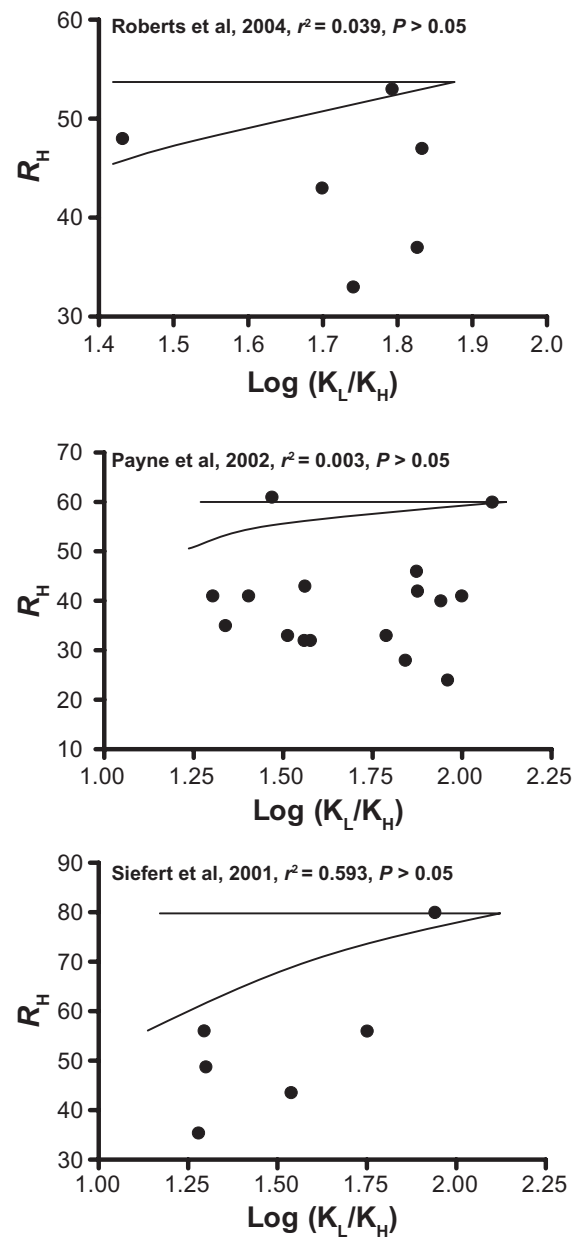

dobutamine) consistently follows a trend of higher $\boldsymbol{R}_{\mathrm{H}}$ for agonists with higher $\log \mathrm{K}_{\mathrm{L}} / \mathrm{K}_{\mathrm{H}}$.

Using $\left[{ }^{3} \mathrm{H}\right] \mathrm{DHA}$ as an antagonist, a significant relationship was obtained (Figure 6). However, it is most probable that had the out-players (zinterol, procaterol, and ephedrine) been tested, a result of no significant relationship would have been obtained as with $\left[{ }^{125} \mathrm{I}\right] \mathrm{CYP}$.

\section{Determination of dissociation constants} for radioactive antagonists at $\beta_{2}-A R$ and $\beta_{2}$-AR density

Table 1 shows the dissociation constants $\left(\mathrm{K}_{\mathrm{d}}\right)$ we obtained for $\left[{ }^{125} \mathrm{I}\right] \mathrm{CYP}$ at $\beta_{2}$-AR in different membrane types. $\mathrm{K}_{\mathrm{d}}$ For $\left[{ }^{3} \mathrm{H}\right] \mathrm{DHA}$ in naïve $\mathrm{H} \beta \mathrm{ARH}$ membranes was $55.7 \pm 7.1 \mathrm{pM}$. Also shown in Table 1 are the $\beta_{2}-A R$ densities $\left(B_{\max }\right)$ in all four membrane types.

\section{Discussion}

Using a unique approach, in the present study we show the insufficiency of the traditionally-accepted TCM,
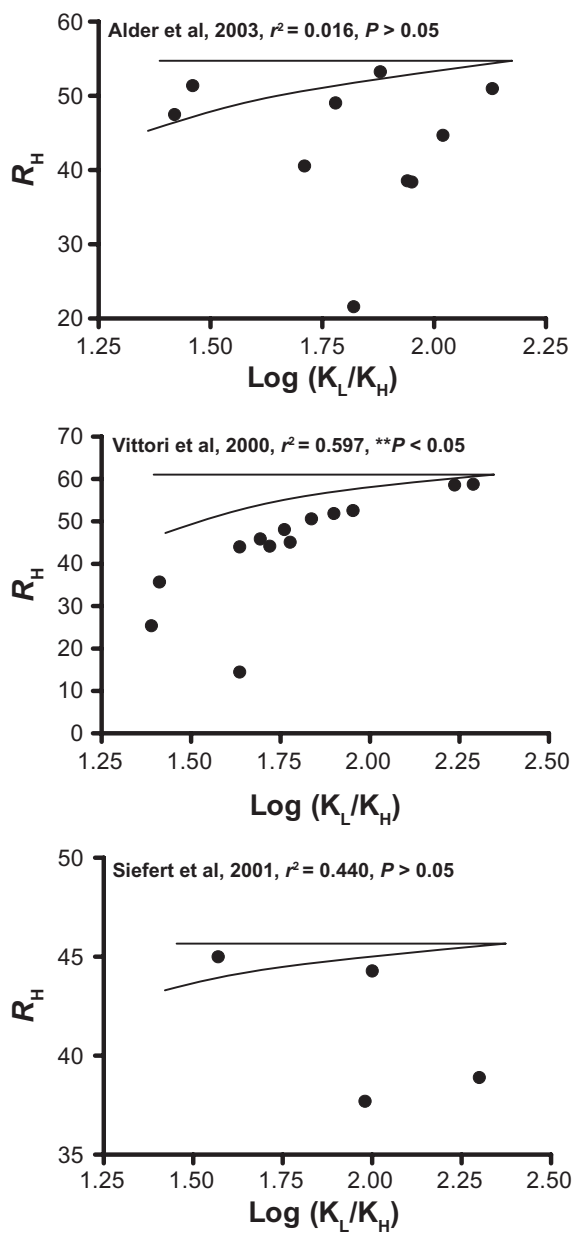

Figure 3 (Continued) 

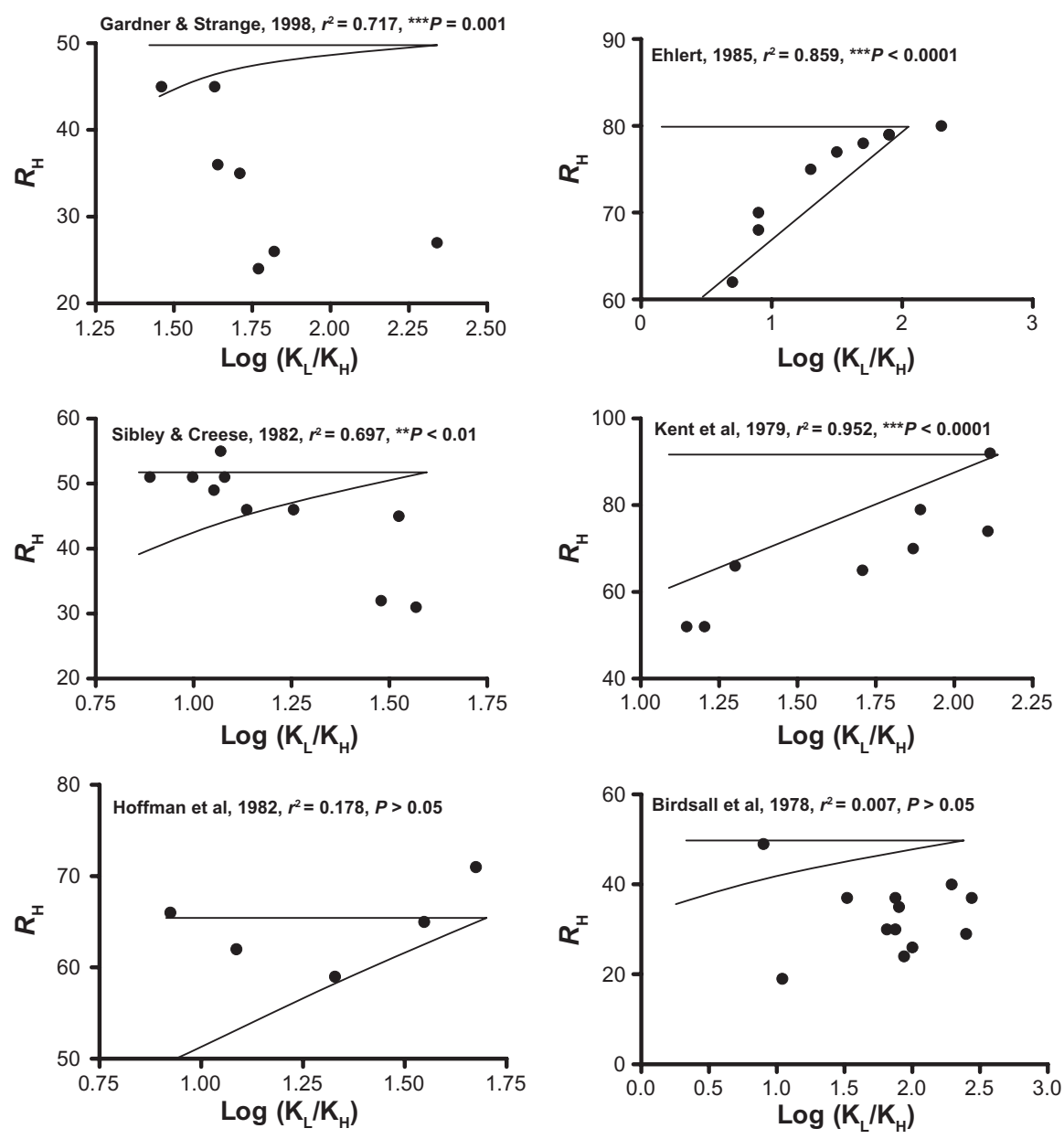

Figure 3 Experimental $\boldsymbol{R}_{H}$ 's do not fall within the range predicted by the TCM for a variety of GPCRs in most studies. Upper lines and lower curves represent the $R_{H}$ 's predicted by the TCM in the extremes of agonist-independent and agonist-dependent coupling of receptors to G-protein, respectively. Abbreviations are as in Figure I.

thus revealing the possible reasons behind inconsistent correlations in the literature between in vitro functional efficacy of GPCR agonists and binding parameters derived from the TCM. By careful analysis of binding data in the literature for various GPCRs, we have shown that the experimental relationships between binding parameters $\left[\log \mathrm{K}_{\mathrm{L}} / \mathrm{K}_{\mathrm{H}}\right.$ and $\boldsymbol{R}_{\mathrm{H}}$ ] deviate from the simulations of the relationships that the TCM necessitates (Figure 3). Our own work obtained the same result for $\beta_{2}$-AR agonists in a variety of membrane types and using two different radioactive antagonists (Figures 5 and 6). It is worth mentioning that having some experimental data that follow the predictions of the TCM does not validate the model in this case, since obtaining data inconsistent with an equilibrium model even once indicates its insufficiency.

The novelty of our approach lies in testing relationships between binding parameters $\left(\log \mathrm{K}_{\mathrm{L}} / \mathrm{K}_{\mathrm{H}}\right.$ and $\left.\boldsymbol{R}_{\mathrm{H}}\right)$. The stringency imposed by the TCM of these relationships allowed us to reveal discrepancies that could not be revealed by the much less stringent binding-functional correlations. In other words, even the datasets in the literature that were thought to be consistent with the TCM (based on binding-functional correlations) are generally not so (based on binding-binding relationships).

Thermodynamically, the only way to explain the complex $\log \mathrm{K}_{\mathrm{L}} / \mathrm{K}_{\mathrm{H}}$ versus $\boldsymbol{R}_{\mathrm{H}}$ relationships shown in this study is to recognize that the ternary complex is not simply 'ternary'; ie, other players are included that allosterically modulate receptor affinity. A considerable amount of evidence is cumulating for allosteric modulation of affinity in GPCRs. ${ }^{28,39-46}$ In a review article different models that incorporated allosterism into the ternary complex model were discussed and its impact on ligand affinity was described. However, the authors finally pointed implicitly to a conclusion similar ours of discrediting the TCM after presenting experimental observations where 'accessory molecules' or 'coupling partners' modulated the affinities of receptors for agonists. ${ }^{41}$ The authors concluded: "Some other additions to the list of GPCR coupling partners 


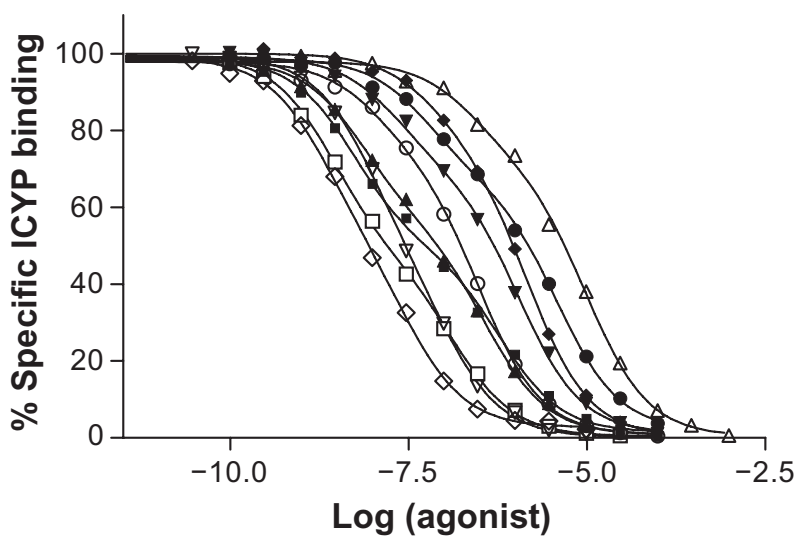

Figure 4 Typical ligand competition curves obtained for the agonists tested in naive $\mathrm{H} \beta A R H$ membranes against $\left[{ }^{125} \mathrm{I}\right] \mathrm{CYP}$. Each curve is representative of an average of 6 experiments. $(\nabla)$ procaterol, $(\diamond)$ zinterol, $(\circ)$ tulobuterol, $(\bullet)$ dobutamine, () isoproterenol, (*) epinephrine, (४) fenoterol, ( $\mathbf{(})$ albuterol, $(\bullet)$ terbutaline, $(\triangle)$ ephedrine.

promise to quash the concept of the receptor-G protein signaling hierarchy altogether'.

So, our study is not the first to bring to focus the effect of allosterism on ligand affinity in GPCRs. However, we have two very significant additions to what have been discovered so far about allosteric modulators. First, we show here that allosteric modulation is concluded from analysis of simple binding experiments. This is in contrast with the above-mentioned citations which involved evaluations of the effect of 'adding' an allosteric modulator on receptor affinity for an agonist. Second, our analysis here shows that allosteric modulators exist naturally or in experimental environments for most GPCRs in most systems because, to our knowledge, their presence is the only way to explain complex $\log \mathrm{K}_{\mathrm{L}} / \mathrm{K}_{\mathrm{H}}$ versus $\boldsymbol{R}_{\mathrm{H}}$ relationships (see below). This is in contrast with the citations above which show that a given molecule or ion in a given concentration 'can' modulate binding properties, but whether this modulation does exist naturally remains to be proven.

Now, to appreciate the importance of incorporating allosteric modulation in explaining binding properties, we have to show how it accommodates binding data not accommodated by the TCM and its extensions. As we can see from Figures 3, 5 and 6, the inconsistency of experimental data with the TCM can be summarized in that $\log \mathrm{K}_{\mathrm{L}} / \mathrm{K}_{\mathrm{H}}$ does not predict $\boldsymbol{R}_{\mathrm{H}}$. This inconsistency is stylized in the simplest form in Figure 7, in which two agonists with the same log $\mathrm{K}_{\mathrm{L}} / \mathrm{K}_{\mathrm{H}}$ can have different $\boldsymbol{R}_{\mathrm{H}}$ values, inconsistently with the TCM, which necessitates that such agonists should have the same $\boldsymbol{R}_{\mathrm{H}}$.

Several assumptions have to be made to enable a model of allosteric modulation explaining Figure 7. These assumptions are substantiated by many observations as detailed below. First, there should be several allosteric modulators that associate
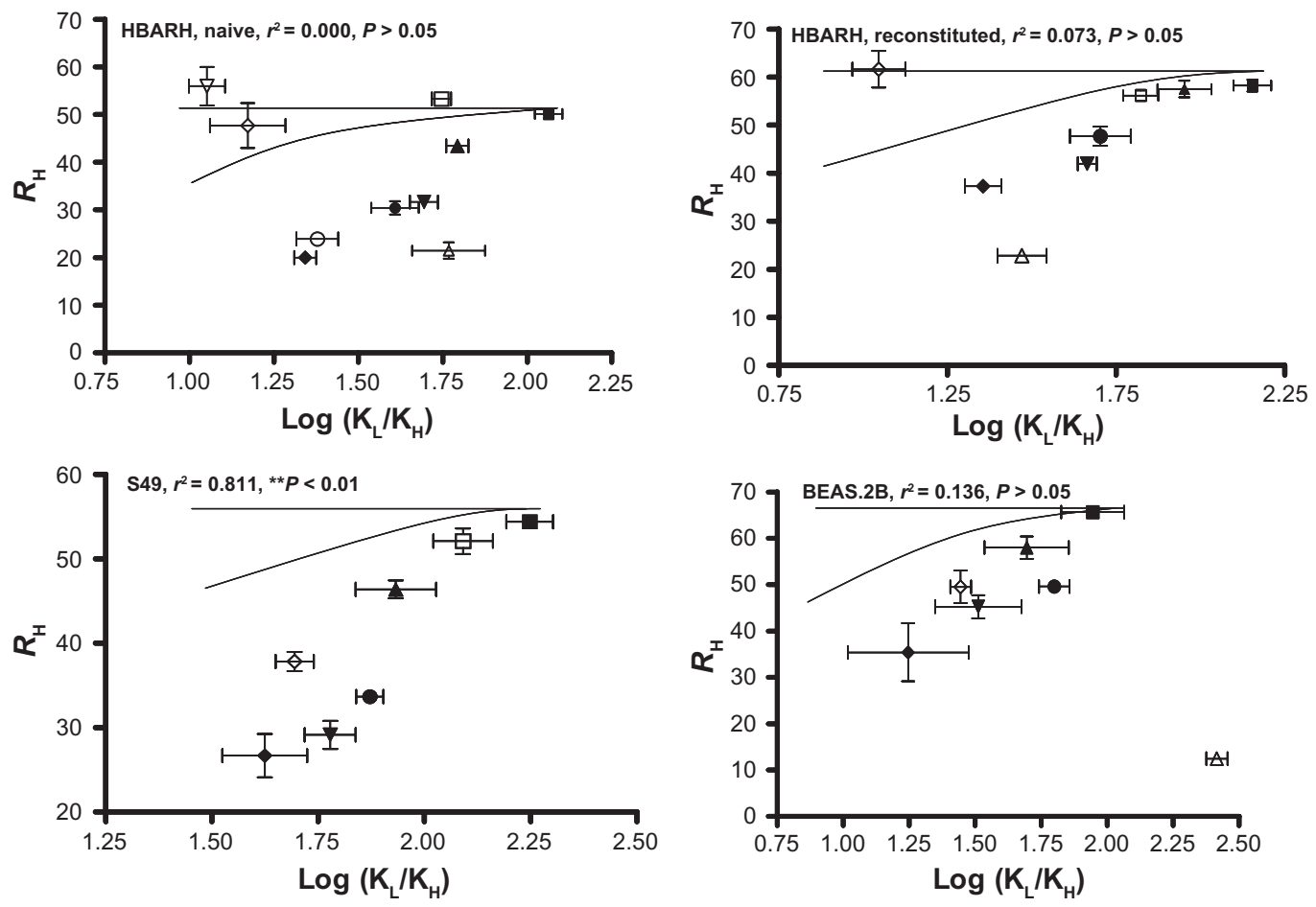

Figure 5 Experimental $\boldsymbol{R}_{H}$ 's do not fall within the range predicted by the TCM for $\beta_{2}$-AR agonists in a variety of membranes. [25I]CYP was used as a radioactive antagonist. The upper line and lower curve represent, respectively, the highest and the lowest theoretical $R_{H}$ 's predicted by the TCM. Each point is an average of 6 (naive H $\beta A R H$ ), 9 (reconstituted H $\beta A R H$ ), 5 (S49), or 3 experiments (BEAS.2B). Error bars represent SEM's. 


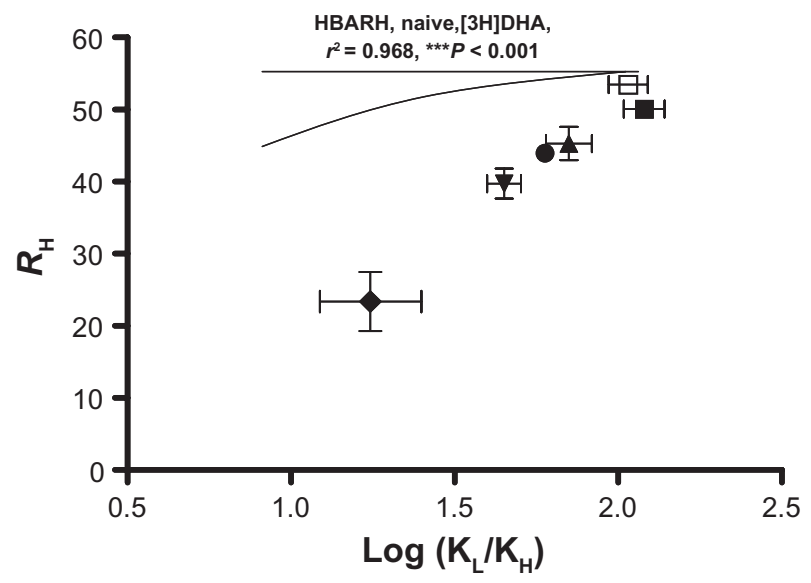

Figure 6 Experimental $\boldsymbol{R}_{\mathrm{H}}$ 's do not fall within the range predicted by the TCM for $\beta_{2}$-AR in $\mathrm{H} \beta A R H$ membranes. [ $\left.{ }^{3} \mathrm{H}\right] \mathrm{DHA}$ was used as a radioactive antagonist. Upper line and lower curve represent, respectively, the highest and the lowest theoretical $\boldsymbol{R}_{\mathrm{H}}$ s predicted by the TCM. Each point is an average of 3-5 experiments. Error bars represent SEM's.

with a given receptor and modify its affinity for different agonists. Second, different allosteric modulators induce different receptor conformations. Third, the induction of a given conformation changes the difference between the affinities of two different agonists for the receptor as compared with before the association of the allosteric modulator. In other words, a receptor with an affinity for agonist $A$ that is 10-fold higher than for agonist $B$ before association with the allosteric modulator may have an affinity for A that is, say, 100-fold higher than for B after association with the modulator. Fourth, at least some allosteric modulators are limited (lower in concentration than the receptor). Fifth, an allosteric modulator can bind to coupled and/or uncoupled receptors (different observations require different assumptions regarding the receptor species to which the allosteric modulator binds). The 'allosteric modulators model' is the name we give for our model that includes the aforementioned assumptions.

Figure 7 can be explained by the allosteric modulators model as follows. An allosteric modulator (a) associates with the receptor (both coupled and uncoupled forms), increasing its affinity for agonist $\mathrm{A}$ more than for agonist $\mathrm{B}$. The affinity of receptor species for $A$ is as follows: $R(a) G>R(a)>R$. Similarly, an allosteric modulator (b) associates with the receptor (both coupled and uncoupled forms), increasing its affinity for B more than for A. The affinity for B is

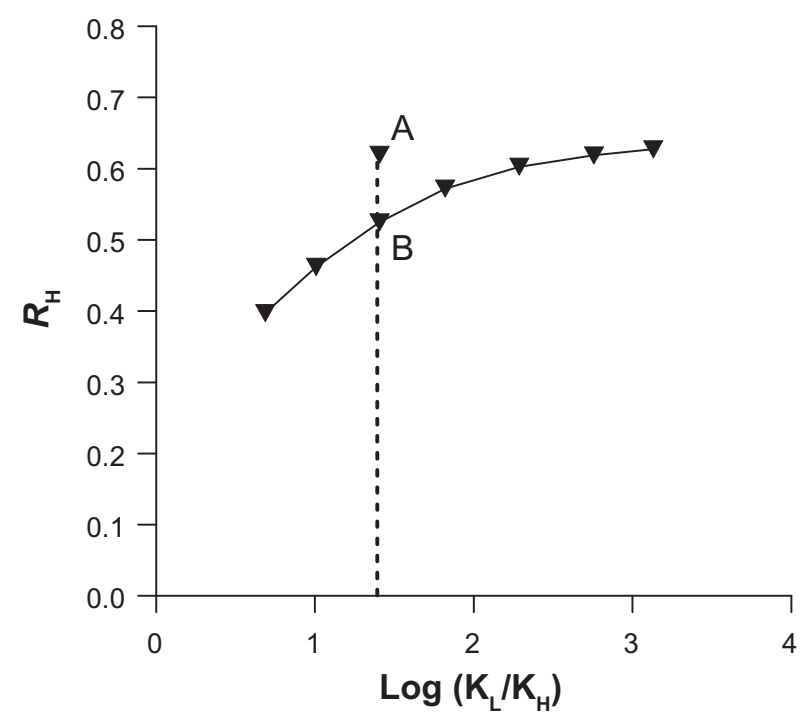

Figure $7 \mathrm{~A}$ stylized representation of binding observations that are inconsistent with the TCM. Notice that two agonists $\left(A\right.$ and $B$ ) with the same $\log K_{L} / K_{H}$ can have different $\boldsymbol{R}_{\mathrm{H}}$ values, which is inconsistent with the TCM.

$\mathrm{R}(\mathrm{b}) \mathrm{G}>\mathrm{R}(\mathrm{b})>\mathrm{R}$. For both agonists, the receptors associated with a modulator are recognized in 2-site analysis as highaffinity sites, whether or not they are coupled to G-protein. Also, (b) is less available than (a), and both are lower in concentration than the receptor. Moreover, we have to assume that the $\log \mathrm{K}_{\mathrm{L}} / \mathrm{K}_{\mathrm{H}}$ intrinsic to $\mathrm{B}$ (ie, in absence of (a) and (b)) is higher than the $\log \mathrm{K}_{\mathrm{L}} / \mathrm{K}_{\mathrm{H}}$ intrinsic to A. However, when the two agonists are compared at a receptor system including both (a) and (b), the following happens. The abundance of (a) compensates for the low intrinsic $\log \mathrm{K}_{\mathrm{L}} / \mathrm{K}_{\mathrm{H}}$ of $\mathrm{A}$, thus bringing the $\log \mathrm{K}_{\mathrm{L}} / \mathrm{K}_{\mathrm{H}}$ for A measured in this system to the level of the measured $\log \mathrm{K}_{\mathrm{L}} / \mathrm{K}_{\mathrm{H}}$ for $\mathrm{B}$, which is compromised by the shortage of (b). Also, the abundance of (a) causes the formation of a higher fraction of R(a)G and R(a), as compared with the fraction of R(b)G and R(b) and, therefore, the $\boldsymbol{R}_{\mathrm{H}}$ for A would be higher than the $\boldsymbol{R}_{\mathrm{H}}$ for $\mathrm{B}$.

This type of explanation is the only way by which we have been able so far to account for the complex $\log \mathrm{K}_{\mathrm{L}} / \mathrm{K}_{\mathrm{H}}$ versus $\boldsymbol{R}_{\mathrm{H}}$ relationships obtained in our and others' studies.

The several assumptions made in our model are substantiated by many observations in the literature. For example, agonist-specific conformations have been proposed in several studies. $^{2,29,30,33}$

Table I Dissociation constants $\left(\mathrm{K}_{\mathrm{d}}\right)$ for $\left[{ }^{125} \mathrm{I}\right] \mathrm{CYP}$ at $\beta_{2}-\mathrm{AR}$ and densities $\left(\mathrm{B}_{\max }\right.$ 's) of $\beta_{2}-\mathrm{AR}$

\begin{tabular}{lllll}
\hline Membrane type & Naïve H $\beta$ ARH & Reconstituted H $\beta$ ARH & S49 & BEAS.2B \\
\hline $\mathrm{K}_{\mathrm{d}}$ for $\left[{ }^{125}\right]$ CYP $(\mathrm{pM})$ & $26.8 \pm 2.0$ & $11.3 \pm 0.6$ & $24.8 \pm 1.7$ & $15.8 \pm 0.6$ \\
$\mathrm{~B}_{\text {max }}$ (pmole/mg protein) & 4.76 & 4.40 & 0.45 & 0.24 \\
\hline
\end{tabular}

Notes: Data are represented as means \pm SEM of two experiments. 
As for allosteric modulators that modulate $\mathrm{K}_{\mathrm{L}} / \mathrm{K}_{\mathrm{H}}$ and/or $\boldsymbol{R}_{\mathrm{H}}$ differently for different agonist, calcyon, a receptor crosstalk protein, reduced $\boldsymbol{R}_{\mathrm{H}}$ for dopamine and SKF82958 at $\mathrm{D}_{1}$-dopamine receptor without affecting their $\mathrm{K}_{\mathrm{L}}$ or $\mathrm{K}_{\mathrm{H}}$ values. ${ }^{40}$ Importantly, calcyon decreased the difference between $\boldsymbol{R}_{\mathrm{H}}$ values of the two $\mathrm{D}_{1}$-agonists from $22 \%$ to $2 \%$.

In fact, the allosteric modulators do not need to be only newly-recognized entities, but a thermodynamic understanding of molecules already known to interact functionally with GPCR brings to conclusion that they are, in a sense, allosteric modulators. For example, it is well-established that GPCR agonists increase the affinity of GPCR for many molecules, such as PKA and $\beta$ ARK. Thermodynamics requires that any of these molecules should then similarly increase the affinity of the receptor for the agonist. This understanding has been made note of in a recent review of allosteric modulation ${ }^{45}$ by mentioning that the expanding list of GPCR-interacting proteins are examples of endogenous allosteric GPCR modulators.

Allosteric modulators need not be only intracellular molecules but can also be ions, ${ }^{43,44}$ membrane proteins, ${ }^{39}$ or lipids. ${ }^{45}$ For example, absence of $\mathrm{Ca}^{2+}$ decreased the affinity of GABA for GABAB receptor 25.2-fold while it had no effect on affinity of bacolfen. ${ }^{44}$ With dopamine $\mathrm{D}_{2}$ receptors, replacing $\mathrm{Na}^{+}$in the reaction mixture with $\mathrm{N}$-methyl D-glucamine increased $\log \mathrm{K}_{\mathrm{L}} / \mathrm{K}_{\mathrm{H}}$ by 0.21 for the partial agonist aplindore and by 0.35 for dopamine. Yet this replacement increased $\boldsymbol{R}_{\mathrm{H}}$ disproportionately by $37.38 \%$ and $7.10 \%$ for aplindore and dopamine, respectively. ${ }^{43}$ In a third example, a single transmembrane domain protein called RAMP3 (receptor-activity-modifying protein 3 ) increased the affinity of human calcitonin receptor for rat amylin but not for calcitonin. ${ }^{39}$ It can be appreciated now that the recognition of allosteric modulators allows much more flexibility in $\boldsymbol{R}_{\mathrm{H}}$ versus $\log \mathrm{K}_{\mathrm{L}} / \mathrm{K}_{\mathrm{H}}$ relationship than allowed by the TCM and its extensions.

In our experimental settings, the concentration of ions and $\mathrm{pH}$ of buffers we used should have influenced the relationship between $\boldsymbol{R}_{\mathrm{H}}$ and $\log \mathrm{K}_{\mathrm{L}} / \mathrm{K}_{\mathrm{H}}$. Had other concentrations and $\mathrm{pH}$ values been used we should have observed different relationships. However, we postulate that an observation will prove consistent no matter what conditions are used; ie, relationships that cannot be explained by the TCM or its extensions.

Our work draws attention to binding-binding relationships as very useful tools for understanding receptor theory and shows that they can be simpler and more definite than the traditionally-applied binding-functional correlations. We did not aim to construct a mass-action scheme for our model since incorporating allosterism in a model is associated with extreme complexity ${ }^{41}$ and is unlikely to have significant practical predictive applicability. On the other hand, the restricted simple forms, such as the allosteric 2-state model, will inevitably fail to explain some allosteric behaviors, as pointed out in a recent review. ${ }^{45}$

Finally, the importance of our work lies in four achievements. First, we invented a novel approach that proved the insufficiency of the ternary complex model and its extensions. Second, this insufficiency of the TCM may account for inconsistency of efficacy-affinity correlations. Third, we provided a model that accounts for binding data inconsistent with the TCM and, at the same time, reveals allosterism intrinsic to various receptor systems. Fourth, our model provides the theoretical basis for deriving a novel binding parameter that correlates with agonist efficacy in our and others' work more significantly and consistently than the parameters used so far (manuscript in preparation).

\section{Acknowledgments}

The authors thank the Department of Integrative Biology and Pharmacology, University of Texas/Houston, Houston, TX, for financial support. The authors also thank Dr Richard Clark and Ms Jacky Friedman (University of Texas at Houston, Health Science Center, Houston) for providing binding and functional protocols as well as [ $\left.{ }^{125} \mathrm{I}\right] \mathrm{ICY}$.

\section{Disclosure}

The authors report no conflicts of interest in this work.

\section{References}

1. De Lean A, Stadel JM, Lefkowitz RJ. A ternary complex model explains the agonist-specific binding properties of the adenylate cyclase-coupled beta-adrenergic receptor. J Bio Chem. 1980;255:7108-7117.

2. Seifert R, Wenzel-Seifert K, Gether U, Kobilka B. Functional difference between full and partial agonists: evidence for ligand-specific receptor conformations. J Pharmacol Exp Ther. 2001;297:1218-1226.

3. Vittori S, Lorenzen A, Stannek C, et al. N-Cycloalkyl Derivatives of adenosine and 1-Deazaadenosine as agonists and partial agonists of the $\mathrm{A}_{1}$ adenosine receptor. J Med Chem. 2000;43:250-260.

4. Kent R, De Lean A, Lefkowitz R. A Quantitative analysis of betaadrenergic receptor interactions: resolution of high and low affinity states of the receptor by computer modeling of ligand binding data. Mol Pharmacol. 1980;17:14-23.

5. Birdsall N, Burgen A, Hulme E. The binding of agonists to brain muscharinic receptors. Mol Pharmacol. 1978;14:723-736.

6. Lefkowitz R, Mullikin D, Caron M. Regulation of $\beta$-adrenergic beceptors by guanyl-5' -yl imidophosphate and other purine nucleotides. J Biol Chem. 1976;251:4686-4692.

7. Christopoulos A, Grant M, El-Fakahany E. Transducer abstraction; a novel approach to the detection of partial agonist efficacy in radioligand binding studies. J Pharmacol Toxicol Methods. 2000;43:55-67.

8. Tolkovsky A, Levitzki A. Mode of coupling between the beta-adrenergic receptor and adenylate cyclase in turkey erythrocytes. Biochemistry. 1978;17:3795-3810. 
9. Boeyaems J, Dumont J. Quantitative analysis of the binding of ligands to their receptors. J Cyclic Nucleotide Res. 1975;1:123-142.

10. Sibley D, Creese I. Interaction of ergot alkaloids with anterior pituitary D-2 dopamine receptors. Mol Pharmacol. 1982;23:585-593.

11. Ehlert F. The relationship between muscarinic receptor occupancy and adenylate cycalse inhibition in the rabbit myocardium. Mol Pharmacol. $1985 ; 28: 410-421$

12. Gardner B, Strange P. Agonist action at $\mathrm{D}_{2 \text { (long) }}$ dopamine receptors: ligand binding and functional assays. Br J Pharmacol. 1998;124:978-984.

13. Lahti R, Figur L, Piercey M, Ruppel P, Evans D. Intrinsic activity determinations at the dopamine D2 guanine nucleotide-bindin-coupled receptor: utilization of receptor state binding affinities. Mol Pharmacol. 1992;42:432-438.

14. Malmberg A, Mohell N, Höök B, Johansson A, Hacksell U, Nordvall G. Interactions of ligands with active and inactive conformations of the dopamine D receptor. Eur J Pharmacol. 1998;346:299-307.

15. Watson J, Collin L, Ho M, et al. 5-HT ${ }_{1 \mathrm{~A}}$ receptor agonist-antagonist binding affinity differences as a measure of intrinsic activity in recombinant and native tissue systems. Br J Pharmacol. 2000;130:1108-1114.

16. Payne S, Johansson A, Strange P. Mechanisms of ligand binding and efficacy at the human $\mathrm{D}_{2 \text { (short) }}$ dopamine receptor. J Neurochem. 2002;82: 1106-1117.

17. Egan C, Grinde E, Dupre A, et al. Agonist high and low affinity state ratios predict drug intrinsic activity and a revised ternary complex mechanism at serotonin $5-\mathrm{HT}_{2 \mathrm{~A}}$ and $5-\mathrm{HT}_{2 \mathrm{C}}$ receptors. Synapse. 2000;35:144-150.

18. Fitzgerald L, Conklin D, Krause C, et al. High-affinity agonist binding correlates with efficacy (intrinsic activity) at the human serotonin 5- $\mathrm{HT}_{2 \mathrm{~A}}$ and 5- $\mathrm{HT}_{2 \mathrm{C}}$ receptors: evidence favoring the ternary complex and two-state models of agonist action. J Neurochem. 1999;72: 2127-2134.

19. Newman-Tancredi A, Verriele L, Touzard M, Millan M. Efficacy of antipsychotic agents at human $5-\mathrm{HT}_{1 \mathrm{~A}}$ receptors determined by $\left[{ }^{3} \mathrm{H}\right]$ WAY 100,635 binding affinity ratios: relationship to efficacy for G-protein activation. Eur J Pharmacol. 2001;428:177-184.

20. Hoffman B, Michel T, Brenneman T, Lefkowitz R. Interactions of agonists with platelet $\alpha_{2}$-adrenergic receptors. Endocrinology. 1982;110:926-932.

21. Samama P, Cotecchia S, Costa T, Lefkowitz R. A mutation-induced activated state of the beta 2-adrenergic receptor. Extending the ternary complex model. J Biol Chem. 1993;268:4625-4636.

22. Van Schaick E, Mathôt R, Gubbens-Stibbe J, et al. 8-Alkylaminosubstituted analogs of N6-cyclopentyladenosine are partial agonists for the cardiovascular adenosine A1 receptors in vivo. J Pharmacol Exp Ther. 1997;283:800-808.

23. Roelen H, Veldman N, Spek A, Kunzel J, Mathot R, IJzerman A. N6 C8-disubstituted adenosine derivatives as partial agonists for adenosine A receptors. J Med Chem. 1996;39:1463-1471.

24. Egan C, Grinde E, Dupre A, et al. Agonist high and low affinity state ratios predict drug intrinsic activity and a revised ternary complex mechanism at serotonin 5-HT(2A) and 5-HT(2C) receptors. Synapse. 2000;35:144-150.

25. Assie MB, Cosi C, Wouter K. Correlation between low/high affinity ratios for 5-HT1 receptors and intrinsic activity. Eur J Pharmacol. 1999;386:97-103.

26. Van der Wenden EM, Hartog-Witte HR, Roelen HC, et al. 8-substituted adenosine and theophylline-7-riboside analogues as potential partial agonists for the adenosine A1 receptor. Eur J Pharmacol. 1995;290: 189-199.
27. Roberts D, Lin H, Strange P. Investigation of the mechanism of agonist and inverse agonist action at D2 dopamine receptors. Biochem Pharmacol. 2004;67:1657-1665.

28. Alder J, Hacksell U, Strange P. Analysis of molecular determinants of affinity and relative efficacy of a series of R- and S-2-(dipropylamino) tetralins at the 5-HT1A serotonin receptor. Br J Pharmacol. 2003;138: 1129-1139.

29. Kenakin T. Agonist-specific receptor conformations. Trends Pharmacol Sci. 1997;18:416-417.

30. Hosohata Y, Varga E, Stropova D, et al. Mutation W284L of the human delta opioid receptor reveals agonist specific receptor conformations for activation. Life Sci. 2001;68:2233-2242.

31. Weiss J, Morgan P, Lutz M, Kenakin T. The cubic ternary complex model I. Model description. J Theor Biol. 1996;178:151-167.

32. Hall DA. Modeling the functional effects of allosteric modulators at pharmacological receptors: an extension of the two-state model of receptor activation. Mol Pharmacol. 2000;58:1412-1423.

33. Strudwick N, Bhogal N, Evans N, Blaney F, Findlay J. Evidence to support a spectrum of active states for the glucagon receptor. Biochem Soc Trans. 2004;32:1037-1039.

34. Roberts D, Lin H, Strange P. Investigation of the mechanism of agonist and inverse agonist action at D2 dopamine receptors. Biochem Pharmacol. 2004;67:1657-1665.

35. Krumins A, Lapeyre JN, Clark RB, Barber R. Evidence for the shuttle model for gp activation of adenylyl cyclase. Biochem Pharmacol. 1997; 54:43-59.

36. Lee E, Linder ME, Gilman AG. Expression of $\alpha$ subunits in Escherichia Coli. Methods Enzymol. 1994;237:146-164.

37. Iniguez-Lluhi JA, Simon MI, Robishaw JD, Gilman AG. G protein beta gamma subunits synthesized in Sf9 cells. Functional characterization and the significance of prenylation of gamma. J Biol Chem. 1992;267:23409-23417.

38. Bradford MM. A rapid and sensitive method for the quantification of microgram quantities of protein utilizing the principle of protein-dye binding. Anal Biochem. 1976;72:248-254.

39. Armour S, Foord S, Kenakin T, Chen WJ. Pharmacological characterization of receptor-activity-modifyins (RAMPs) and the human calcitonin receptor. J Pharmacol Toxicol. 1999;42:217-224.

40. Lidow MS, Roberts A, Zhang L, Koh PO, Lezcano N, Bergson C. Receptor crosstalk protein, calcyon, regulates affinity state of dopamine D1 receptors. Eur J Pharmacol. 2001;427:187-193.

41. Christopoulos A, Kenakin T. G-protein-coupled receptor allosterism and complexing. Pharmacol Rev. 2002;54:323-374.

42. Nanoff C, Waldhoer M, Roka F, Freissmuth M. G protein coupling of the rat A1-adenosine receptor-partial purification of a protein which stabilizes the receptor-G protein association. Neuropharmacol. 1997;36: 1211-1219.

43. Lin H, Saisch S, Strange P. Assays for enhanced activity of low efficacy partial agonists at the D2 dopamine receptor. Br J Pharmacol. 2006;149:291-299.

44. Galvez T, Urwyler S, Prezeau L, et al. $\mathrm{Ca}(2+)$ requirement for highaffinity gamma-aminobutyric acid (GABA) binding at GABA(B) receptors: involvement of serine 269 of the GABA(B)R1 subunit. $M o l$ Pharmacol. 2000;57:419-426.

45. May L, Leach K, Sexton P, Christopoulos A. Allosteric modulation of g protein-coupled receptors. Annu Rev Pharmacol Toxicol. 2007;47: 41-51.

46. Gilchrist A. Modulating G-protein-coupled receptors: from traditional pharmacology to allosterics. Trends Pharmacol Sci. 2007;28:431-437. 


\section{Supplement I}

Here we present our derivation of equations that we used in our spreadsheets to relate the quantities of different receptor species in the context of the TCM:

To calculate $\boldsymbol{R}_{\mathrm{H}}$ predicted by the TCM for an agonist with a given $\log \mathrm{K}_{\mathrm{L}} / \mathrm{K}_{\mathrm{H}}$ we need to calculate the fraction of receptors that is bound to the agonist ([RA] $+[\mathrm{RGA}])$ at different agonist concentrations. The fraction left for binding to radioactive antagonist is then calculated (using a spreadsheet) by subtraction from unity. Then this fraction is plotted against agonist concentration, and $\boldsymbol{R}_{\mathrm{H}}$ as well as $\log \mathrm{K}_{\mathrm{L}} / \mathrm{K}_{\mathrm{H}}$ are obtained using Graph Pad software. So all we need to do mathematically is to solve the equations, based on equilibrium equations and the rule of mass conservation of the TCM, for $[\mathrm{RH}]$ and $[\mathrm{RGH}]$.

The ternary complex model is described diagrammatically as:

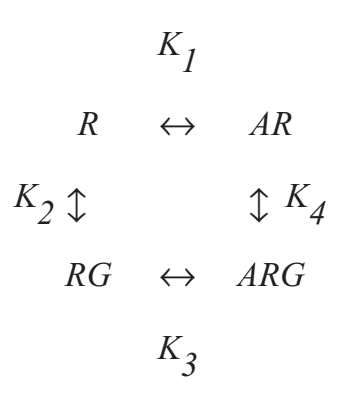

So the equilibrium conditions are:

$$
\begin{aligned}
& K_{1}=\frac{[R][A]}{[R A]} \\
& K_{2}=\frac{[R][G]}{[R G]} \\
& K_{3}=\frac{[R G][A]}{[R G A]} \\
& K_{4}=\frac{[R A][G]}{[R G A]}
\end{aligned}
$$

and the mass conservation conditions are:

$$
r=[R]+[R A]+[R G]+[R G A]
$$

where $r$ is the total receptor amount

$$
g=[G]+[R G]+[R G A]
$$

where $\mathrm{g}$ is the total G-protein amount

In order to solve for [RGA], we use the equilibrium equations to get expressions for [RA], [RG], and [R] in terms of [RGA] as follows:
From 4, $[R A]=\frac{K_{4}[R G A]}{[G]}:$ From (3), $[R G]=\frac{K_{3}[R G A]}{[A]}$

From 1 and $4, \quad[R]=\frac{K_{1}[R A]}{[A]}=\frac{K_{1} K_{4}}{[A][G]}[R G A]$

Insertion of these relationships into equation 5 gives:

$$
r=[R G A]\left(\frac{K_{1} K_{4}}{[A][G]}+\frac{K_{4}}{[G]}+\frac{K_{3}}{[A]}+1\right)
$$

which may be rewritten as:

$$
r=[R G A]\left(\frac{K_{4}}{[G]}\left(1+\frac{K_{1}}{[A]}\right)+1+\frac{K_{3}}{[A]}\right)
$$

Now only the elimination of $[\mathrm{G}]$ remains. From 6 and 3 we can determine that:

$$
[G]=g-[R G]-[R G A]=g-\left(1+\frac{K_{3}}{[A]}\right)[R G A]
$$

Substituting 9 into 8 gives:

$$
r=[R G A]\left(\frac{K_{4}\left(1+\frac{K_{1}}{[A]}\right)}{g-[R G A]\left(1+\frac{K_{3}}{[A]}\right)}+1+\frac{K_{3}}{[A]}\right)
$$

Writing $\left(1+\left(\mathrm{K}_{1} /[\mathrm{A}]\right)\right)$ as $\mathrm{B}_{1}$ and $\left(1+\left(\mathrm{K}_{3} /[\mathrm{A}]\right)\right)$ as $\mathrm{B}_{3}$ gives:

$$
r=[R G A]\left(\frac{K_{4} B_{1}}{g-[R G A] B_{3}}+B_{3}\right)
$$

Multiplying through by $\mathrm{g}-[\mathrm{RGA}] \mathrm{B}_{3}$ gives:

$r g-r B_{3}[R G A]=K_{4} B_{1}[R G A]+g B_{3}[R G A]-B_{3}^{2}[R G A]^{2}$

Then, rearranging these figure:

$$
B_{3}^{2}[R G A]^{2}-\left(r B_{3}+g B_{3}+K_{4} B_{1}\right)[R G A]+r g=0
$$

Solving using the standard solution to a quadratic gives:

$[R G A]=\frac{r B_{3}+g B_{3}+K_{4} B_{1}-\sqrt{\left(r B_{3}+g B_{3}+K_{4} B_{1}\right)^{2}-4 r g B_{3}^{2}}}{2 B_{3}^{2}}$

This rearranges to:

$$
[R G A]=\frac{1}{B_{3}} \cdot \frac{r+g+K_{4} \frac{B_{1}}{B_{3}}-\sqrt{\left(r+g+K_{4} \frac{B_{1}}{B_{3}}\right)^{2}-4 r g}}{2}
$$


In order to calculate the total binding of agonist we also need to know [RA]. We calculate it as follows:

The quantity of receptors not coupled to G-protein (here called $\mathrm{x}$ ) is equal to $[\mathrm{R}]+[\mathrm{RA}]$.

From the equilibrium condition $(1),[R]$ is equal to [RA] K1/[A]. Therefore:

$$
x=\frac{[R A] K_{1}}{[A]}+[R A]=[R A]\left(\frac{K_{1}+[A]}{[A]}\right)
$$

It follows that $[R]+[R A]=[R A]\left(\frac{K_{1}+[A]}{[A]}\right)$.

Therefore: $[R A]=\frac{([R]+[R A])[A]}{K_{1}+[\mathrm{A}]}$

The quantity of receptors not coupled to G-protein $([\mathrm{R}]+[\mathrm{RA}])$ is also equal to $\mathrm{r}-[\mathrm{RG}]-[\mathrm{RGA}]$.

Therefore:

$$
\begin{aligned}
{[R A] } & =(r-[R G A]-[R G]) \frac{[A]}{K_{1}+[A]} \\
& =\left(r-[R G A]\left(1+\frac{K_{3}}{[A]}\right)\right) \frac{[A]}{K_{1}+[A]}
\end{aligned}
$$

But $1+\left(\mathrm{K}_{3} /[\mathrm{A}]\right)$ is $\mathrm{B}_{3}$ and $[\mathrm{A}] /\left(\mathrm{K}_{1}+[\mathrm{A}]\right)$ is $1 / \mathrm{B}_{1}$. Therefore equation 15 becomes:

$$
[R A]=\frac{r-B_{3}[R G A]}{B_{1}}
$$

By inserting the known solution for [RGA] (equation 14) and rearranging we get:

$[R A]=\frac{r}{B_{1}}-\frac{1}{B_{1}} \cdot \frac{r+g+K_{4} \frac{B_{1}}{B_{3}}-\sqrt{\left(r+g+K_{4} \frac{B_{1}}{B_{3}}\right)^{2}-4 r g}}{2}$

Finally, the total amount of receptor bound by agonist at a given agonist concentration is given by the sum of 14 and 17:

$$
\begin{aligned}
& {[R G A]+[R A]=\frac{r}{B_{1}}+\left(\frac{1}{B_{3}}-\frac{1}{B_{1}}\right) .} \\
& \frac{r+g+K_{4} \frac{B_{1}}{B_{3}}-\sqrt{\left(r+g+K_{4} \frac{B_{1}}{B_{3}}\right)^{2}-4 r g}}{2}
\end{aligned}
$$

\section{Publish your work in this journal}

The Journal of Receptor, Ligand and Channel Research is an international, peer-reviewed, open access, online journal. The journal welcomes laboratory and clinical findings in the fields of biological receptors, ligands, channel and signal transduction research including: receptors and signalling; ligands; transporters, pores and channels; binding and activation; receptor regulation; role of receptors in diseases and their treatment; molecular basis of membrane structure and functions; molecular models of membranes. The manuscript management system is completely online and includes a very quick and fair peer-review system. Visit http://www.dovepress.com/ testimonials.php to read real quotes from published authors. 